"Dr. Franklin's own excited, uproariously witty reports to his family, his friends, and his scientific colleagues in Europe and America create an incomparable portrait of science in the eighteenth century. Reading these letters fosters a new affection for our country's foremost and most beloved inventor." -DAVA SOBEL, author of Longitude and Galilea's Daugbter

"This marvelous collection helps rescue Ben Franklin from our impression of him as a genial tinkerer flying kites in the rain. In fact, he was a serious scientist whose letters reveal the scope of his ideas, ranging from daylight savings time to bifocals to magnetism. This book crackles with his wonderful mental energy."

-WALTER ISAACSON, managing editor of Time 
PENNSYLVANIA PAPERBACKS 


\section{THE INGENIOUS}

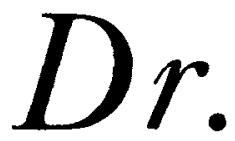

F R A NKLIN

SELECTED SCIENTIFIC LETTERS $\mathrm{OF}$

BENJAMIN FrankLIN

Edited by

NATHAN G. GOODMAN

PHILADELPHIA

University of Pennsylvania Press 
Copyright (C) 1931 University of Pennsylvania Press

All rights reserved

Printed in the United States of America on acid-free paper

1098765432

Published by

University of Pennsylvania Press

Philadelphia, Pennsylvania $1910^{-4} 401$

Library of Congress Catalog Card Number 31-34123

ISBN 0-8122-1067-0 